\title{
Tilfelli mánaðarins - fyrirferð í eista
}

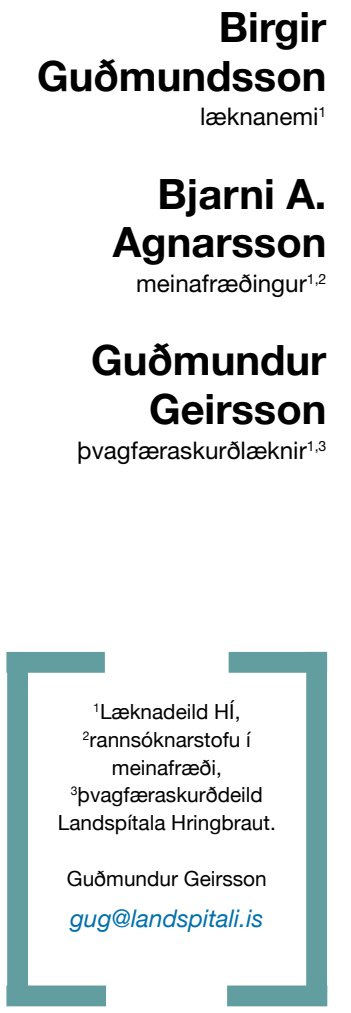

Rúmlega fertugur karlmaður leitaði til pvagfæraskurðlæknis vegna sex mánaða sögu um væga verki í hægra eista. Hann var áður hraustur en vinstra eista sem var launeista (cryptoprchidism) hafði verið fjarlægt pegar hann var barn. Við skoðun preifaðist hægra eista í pung. Рað var í stærra lagi, mjúkt en án fyrirferðar. Fengin var ómskoðun sem sýndi $1 \mathrm{~cm}$ fyrirferð í miðju eista (mynd 1). Æxlisvísar í blóði mældust eðlilegir en

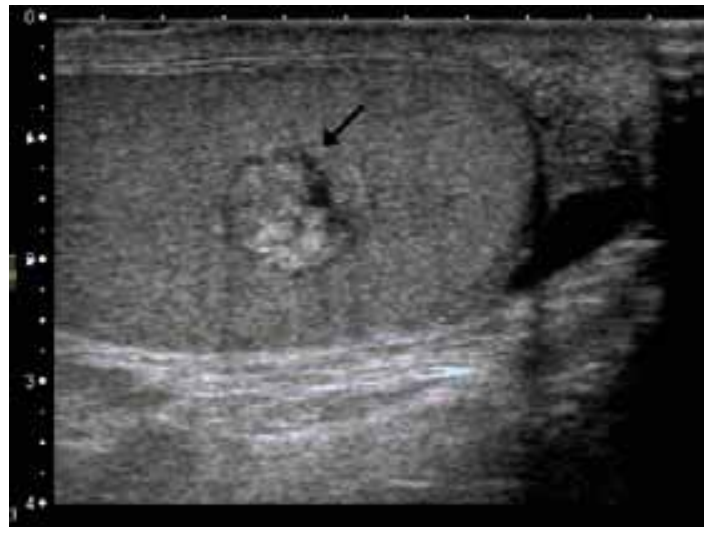

Mynd 1. Ómmynd af eista. testósterón aðeins undir viðmiðunarmörkum, eða 8,45 nmól/L (viðmiðunarmörk 8,6-29 nmól/L). Ákveðið var að taka sýni úr eistanu í opinni aðgerð og er smásjármynd af æxlinu sýnd á mynd 2.

Hver er sjúkdómsgreiningin? Hverjar eru helstu mismunagreiningarnar? Í hverju felst meðferðin?

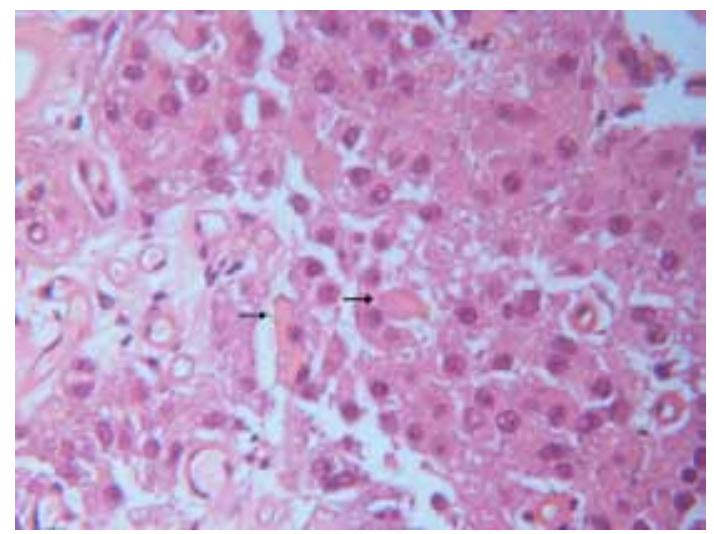

Mynd 2. HE litun af æxxlinu á mynd 1.

\section{Læknadagar 2011}

Á Nordica Hilton 24.-28. janúar. 


\section{Svar við tilfelli mánaðarins}

Hér er um að ræða góðkynja Leydigfrumuæxli í eista. Greining fæst á mynd 2 en par má sjá umfrymisríkar æxlisfrumur sem mynda klasa. Einkennandi eru svokallaðir Reinke kristallar (örvar) sem sjást í umfrymi æxlisfrumna í um priðjungi pessara tilfella. ${ }^{1}$ Leydigfrumur eru staðsettar milli sæðispípla eistnanna og seyta karlkyns hormónum, meðal annars testósteróni, andrósteróni og dehýdróepiandrósteróni. ${ }^{1,} 2$ Leydigfrumuæxli eru algengasta gerð svokallaðra kynstrengs grunnvefsæxla (sex cord stromal tumors). Pau eru sjaldgæf eða 1-3\% allra æxla í eistum og pví mun sjaldgæfari en kímfrumuæxli (germ cell tumors) sem er helsta mismunagreining. ${ }^{1-3}$ Aðrar mismunagreiningareru appendix morgani, eistnalyppubólga, vatnshaull, kólfsæðavíkkun (varicocele), eitilfrumuæxli og sortuæxli. Leydigfrumuæxli geta greinst í öllum aldurshópum en greinast oft milli 5-10 ára og 30-60 ára. Sérstakir áhættupættir eru ekki pekktir líkt og í kímfrumuæxlum. ${ }^{2}$ Pessi æxli eru oftast í kringum 3-5 cm á stærð, vel afmörkuð og gulbrún eða gulhvít á lit sem rekja má til lípíða í frumunum (mynd 3). Hjá börnum eru pau ávallt góðkynja en hjá fullorðnum eru $10 \%$ peirra illkynja. ${ }^{2}$

Leydigfrumæxli seyta oft karlhormónum en einnig er pekkt að pau geti framleitt kvenhormón eins og estrógen. ${ }^{1,2}$ Helstu einkenni ráðast af aldri sjúklings og hvaða hormónum pað seytir. Hjá strákum getur komið fram við testósterónframleiðslu snemmbær kynproski, svo sem stækkun á getnaðarlim, hárvöxtur við kynfæri og stækkun á vöðvum. Hjá fullorðnum karlmönnum eru einkennin yfirleitt minna áberandi. Ef æxlin framleiða estrógen geta brjóst stækkað (gynecomastia), hárdreifing á líkamanum orðið kvenleg og hjá ungum strákum geta kynfæri proskast óeðlilega. Einnig eru pekkt hjá eldri karlmönnum risvandamál, minnkuð kynhvöt og ófrjósemi. ${ }^{1-3}$

Við skoðun preifast oft hnúðar djúpt í eistanu. Leiki vafi á greiningu getur ómskoðun verið hjálpleg. Sést pá ómrýr pétting sem er æðarík við litaflæðisómun, en péttari og ójafnari fyrirferð getur bent til illkynja æxlis. ${ }^{2}$ Pessi æxli greinast yfirleitt í öðru eistanu en í 3\% tilfella eru pau í báðum eistum. ${ }^{1,2}$ Illkynja Leydigfrumuæxli eru oft stærri en $5 \mathrm{~cm}$ og 1 peim sést ífarandi vöxtur, blæðingar og drep. ${ }^{1,}$ 2, 4 Pessir sjúklingar geta haft meinvörp í aftanskinu eitlastöðvum, lifur (45\%), lungum (40\%) eða beinum $(25 \%){ }^{2}$

Niðurstöður blóðrannsókna hjá sjúklingum með Leydigfrumuæxli eru oft ósértækar, en karlkynshormón og estrógen geta verið hækkuð, eðlileg eða jafnvel lækkuð. Æxlisvísar eins og $\alpha$-fetoprotein og human chorionic gonadótrópin eru yfirleitt eðlilegir. ${ }^{2}$ Meðferð felst í brottnámi eistans en eistnasparandi aðgerð kemur einnig til greina, sérstaklega hjá strákum og ungum körlum til að viðhalda frjósemi. Ef æxlið er illkynja er mælt með brottnámi eistans og eitlum í aftanskinurými. ${ }^{1,2}$ Illkynja æxli svara lyfja- og geislameðferð illa og er meðallifun oft um tvö ár. ${ }^{2}$

Í pessu tilfelli var ákveðið að gera eistasparandi aðgerð, enda góðkynja æxli í stöku eista. Tveimur mánuðum frá aðgerð var sjúklingur við góða líðan og testósteróngildi eðlileg.

Petta tilfelli sýnir að æxli í eista geta verið góðkynja og í slíkum tilvikum er hægt að beita eistasparandi aðgerð. Einnig er vert að hafa Leydigfrumuæxli í huga sem mismunagreiningu ef innkirtlaeinkenni fylgja eistnameini.

Pakkir fær Tómas Guðbjartsson fyrir yfirlestur og góðar ábendingar.

\section{Heimildir}

1. Jou P, Maclennan GT. Leydig cell tumor of the testis. J Urol 2009; 181: 2299-300.

2. Al-Agha OM, Axiotis CA. An in-depth look at Leydig cell tumor of the testis. Arch Pathol Lab Med 2007; 131: 311-7.

3. Young RH. Testicular tumors--some new and a few perennial problems. Arch Pathol Lab Med 2008; 132: 548-64.

4. Emerson RE, Ulbright TM. Morphological approach to tumours of the testis and paratestis. J Clin Pathol 2007; 60: 866-80.
Mynd 3. Æxlið eftir brottnám $(A)$ og skorið i tvennt (B).

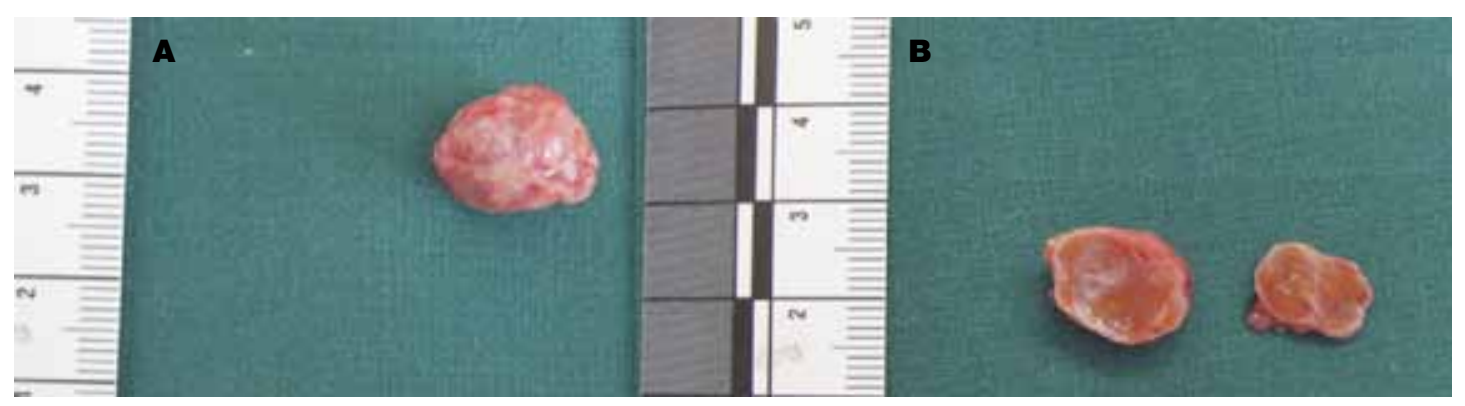

